\title{
A Systematic Operation Program of a Hydropower Plant Based on Minimizing the Principal Stress: Haditha Dam Case Study
}

\author{
Jing Li ${ }^{1}$, Ameen Mohammed Salih Ameen ${ }^{2}$, Thamer Ahmad Mohammad ${ }^{2}$, \\ Nadhir Al-Ansari ${ }^{3, *(D)}$ and Zaher Mundher Yaseen $4, * \mathbb{D}$ \\ 1 Business School, Lanzhou City University, Lanzhou, China; jileaf@lzcu.edu.cn \\ 2 Department of Water Resources, University of Baghdad, Baghdad, Iraq; \\ Ameen7617957@gmail.com (A.M.S.A.); thamer@gmail.com (T.A.M.) \\ 3 Civil, Environmental and Natural Resources Engineering, Lulea University of Technology, \\ 97187 Lulea, Sweden \\ 4 Sustainable Developments in Civil Engineering Research Group, Faculty of Civil Engineering, \\ Ton Duc Thang University, Ho Chi Minh City, Vietnam \\ * Correspondence: nadhir.alansari@ltu.se (N.A.-A.); yaseen@tdtu.edu.vn (Z.M.Y.); \\ Tel.: +46-920-491-858 (N.A.-A.); +84-0163-4987-030 (Z.M.Y.)
}

Received: 24 August 2018; Accepted: 13 September 2018; Published: 18 September 2018

check for updates

\begin{abstract}
Dam operation and management have become more complex recently because of the need for considering hydraulic structure sustainability and environmental protect on. An Earthfill dam that includes a powerhouse system is considered as a significant multipurpose hydraulic structure. Understanding the effects of running hydropower plant turbines on the dam body is one of the major safety concerns for earthfill dams. In this research, dynamic analysis of earthfill dam, integrated with a hydropower plant system containing six vertical Kaplan turbines (i.e., Haditha dam), is investigated. In the first stage of the study, ANSYS-CFX was used to represent one vertical Kaplan turbine unit by designing a three-dimensional (3-D) finite element (FE) model. This model was used to differentiate between the effect of turbine units' operation on dam stability in accordance to maximum and minimum reservoir upstream water levels, and the varying flowrates in a fully open gate condition. In the second stage of the analysis, an ANSYS-static modeling approach was used to develop a 3-D FE earthfill dam model. The water pressure pattern determined on the boundary of the running turbine model is transformed into the pressure at the common area of the dam body with turbines. The model is inspected for maximum and minimum upstream water levels. Findings indicate that the water stress fluctuations on the dam body are proportional to the inverse distance from the turbine region. Also, it was found that the cone and outlet of the hydropower turbine system are the most affected regions when turbine is running. Based on the attained results, a systematic operation program was proposed in order to control the running hydropower plant with minimized principal stress at selected nodes on the dam model and the six turbines.
\end{abstract}

Keywords: earthfill dam; hydropower plant; Kaplan turbine; water principal stress

\section{Introduction}

One of the major concerns of the dam and hydropower system operation is the post-design stage process [1]. As a matter of fact, large hydraulic infrastructures, such as earthfill dams, behave differently during the actual operation, because of the diverse load performances and the nature of in situ conditions. Hence, studying the physical effects like vibration, stress, and mechanical properties degradation are extremely vital for understanding the consequences of operation strategies on the 
sustainability goals of dam operations [2]. Power stations coupled with a large dam represent an important multipurpose hydraulic structure that are used mainly to store water for many water resources engineering requirements, in addition to hydroelectric power generation at low cost [3,4].

The seismic effect on dam bodies was studied by the civil engineering researchers in order to assess their dynamic behaviors. While, the vibrational effect produced by the hydraulic turbines was studied by mechanical engineering researchers to assess their hydraulic performance, due to powerhouse operation. Most of the studies were focused on the modeling and analysis of pressure distribution on turbine draft tube.

Thus, it is necessary to study the impact of vibrational effects due to the powerhouse operation on the dam body, taking into consideration the dam type, the powerhouse type and the turbine type. Studies focusing on the modeling of dynamic behaviors and the hydraulic performance of embankment dams are essential to improving dam safety. However, the effects of vibration, due to powerhouse operation on dam bodies were not found in a single study.

In practice, hydropower operations may yield several undesirable impacts, such as (i) disruption of aquatic ecosystem, (ii) high initial construction cost, (iii) uprooting of human population, (iv) requirement of high quality materials, (v) environmental impacts causes natural habitat loss, (vi) risk of drought, (vii) geological damage, and (viii) increase in unsafe conditions for dam operations [5-7]. In this research, we focus on the effects of a hydropower plant on dam operation safety and sustainability. The optimal operation of turbine units inside the powerhouse has the potential to reduce the generation of vibrations and stresses on the dam body, and the powerhouse infrastructure $[8,9]$. These stresses may vary based on the distance from turbine's running effect, as well as due to control of the turbine units with total and partial loads. The existing literature in this area has primarily investigated the stability of power station with turbines [10,11], and the seismic influence on the dynamic behavior of the dams [12]. Yet, all studies have separately investigated these problems without linking the hydropower plant system represented by the turbines with the influence of operation on dam body. In this research, and for the first time, investigation and assessment for an integrated hydropower plant system with an earthfill dam is carried out.

Several attempts have been made over the past decade to use 3-D finite volume (FV) numerical modeling method for examining how cavitation in turbines [13-17]. These analyses conducted using the Reynolds Navier-Stokes Equation [18], coupled either with the combination of k- $\omega$ shear stress transport turbulence [19] or k- $\varepsilon$ turbulence [14,20]. Continuity formulation is usually used to determine the pressure distribution, velocity, and frequency attributed at different water levels. By contrast, fewer studies have been conducted to reduce the cavitation in turbine draft tubes, improving the hydraulic performance [14]. Other researchers have aimed to reduce the vibration effects of a running powerhouse by creating a 3-D numerical model that represents a specific hydropower station system [8, 21,22]. These studies have focused their investigations on examining the interactions between fluid and structure systems, under dynamic and kinematic conditions.

Many studies have discussed the dynamic behavior of earthfill dams by evaluating and analyzing the seismic effect on the interconnected dam-reservoir-foundation system. Such an analysis is performed by using either one or a combination of the following methods: field testing, theoretical analysis, or finite element modeling. One of the earliest attempts in this scope was conducted by [23], who analyzed and simplified the fundamental vibration mode response of the gravity dam by assuming that (a) concrete dams with full and empty reservoirs are supported on a rigid foundation rock bed, and that (b) concrete dams with full and empty reservoirs are supported on a flexible foundation rock. Watanabe et al. (1996) developed 2-D and 3-D model analyses for earthfill dams based on a finite element method to analyze the effect of the parameters (e.g., strain, stress, acceleration, and deformation) on the dam foundation [24]. Lotfi (2003) discussed the reservoir size effects on the dynamic behavior of concrete gravity dams [25]. Jafari and Davoodi (2004) created 2-D and 3-D models of embanked dam using ANSYS for dynamic analysis [26]. ANSYS software is an American engineering solution based in Canonsburg, Pennsylvania. The soil properties were calculated 
using level dynamic tests while the effects of other information such as water depth, abutments, and foundation parameters were considered in the modeling process.

The dam-foundation-rock interaction were analyzed by [27] using a 3-D FE numerical model that represents an earthfill dam, and by using IZIIS software to determine the dynamic behavior of the earthfill dam material. Previous studies were also conducted on the dynamic analysis of hydropower plant water system $[14,28,29]$. However, in these studies, the dynamic behavior of dams have been studied without including the influence of hydropower plants [30].

To date, no research has investigated the impact of vibration resulting from turbine operation on the stability of a hydropower plant integrated with the dam body. This study simulates the above problem taking Haditha dam in Iraq as a case study. The simulation includes two stages. The first stage focuses on using a finite volume technique to simulate turbine operation, while the second stage includes using 3-D FE to simulate the stability of the dam body, together with the powerhouse, taking into consideration the boundary pressure pattern obtained from the first simulation stage. The complex dam-powerhouse-reservoir-foundation system interactions were also considered.

\section{Description of the Dam with an Integrated Powerhouse}

Haditha dam is an earthfill dam that is located on a narrow stretch of the Euphrates River at $34^{\circ} 12^{\prime}$ latitude and $42^{\circ} 21^{\prime}$ longitude, about $8 \mathrm{~km}$ northwest of Haditha town, which is about $270 \mathrm{~km}$ northwest of Baghdad (Figure 1). The construction of the dam started in 1977 and it was in operation in 1988. The maximum height of the dam is $57 \mathrm{~m}$, and the total length is $9064 \mathrm{~m}$. From the deepest point at the river channel and the dam crest level is $154 \mathrm{~m}$ above sea level (a.s.l.). The normal operation water level is $143 \mathrm{~m}$ (a.s.l.), while the maximum operation water level is $147 \mathrm{~m}$ (a.s.l.). The maximum flood water level is $152 \mathrm{~m}$ (a.s.l.). The total storage capacity of the dam is 6 billion cubic meters at $143 \mathrm{~m}$ (a.s.l.) [31,32].

The power station is an integral part of the dam, containing six vertical Kaplan turbines capable of producing $660 \mathrm{MW}$ power. The turbines are installed in a hydro combined unit comprising both a spillway and a hydropower plant in one structure. The Haditha dam has a multipurpose structure and it is used to generate hydroelectricity, regulate the flow of the Euphrates, and provide water for irrigation. The Haditha dam is the second largest hydroelectric contributor to the power system in Iraq after the Mosul dam. Table 1 displays general information on the dam. Figure $2 \mathrm{a}, \mathrm{b}$ exhibit a graphical presentation of the dam and the turbine system dimensions. This information is crucial toward constructing the 3-D FE model (Figure 2b).

Table 1. The dimensions and hydraulic information of Haditha dam.

\begin{tabular}{lcc}
\hline \multicolumn{3}{c}{ Unit } \\
\hline Location of Haditha dam & \multicolumn{2}{c}{$34^{\circ} 12^{\prime} 25^{\prime \prime} \mathrm{N} 42^{\circ} 21^{\prime} 18^{\prime \prime} \mathrm{E}$} \\
\hline & \multicolumn{1}{c}{ Dam Dimensions } & \\
\hline Dam height & $\mathrm{m}$ & 57 \\
Length & $\mathrm{m}$ & 9000 \\
\hline \multicolumn{1}{c}{ Hydraulic Information's } \\
\hline Type of turbines & & Vertical Kaplan \\
Number of units & $\mathrm{MW}$ & 6 \\
Install capacity & $\mathrm{m}$ & $6 \times 110=660$ \\
Length of unit & $\mathrm{m}$ & 67.35 \\
Flood level & $\mathrm{m}$ & 150.2 \\
Maximum drawdown in upstream water level & $\mathrm{m}$ & 129 \\
Downstream water level & $\mathrm{m} / \mathrm{s}$ & $6 \times 339=2034$ \\
Maximum powerhouse discharge & & \\
\hline
\end{tabular}




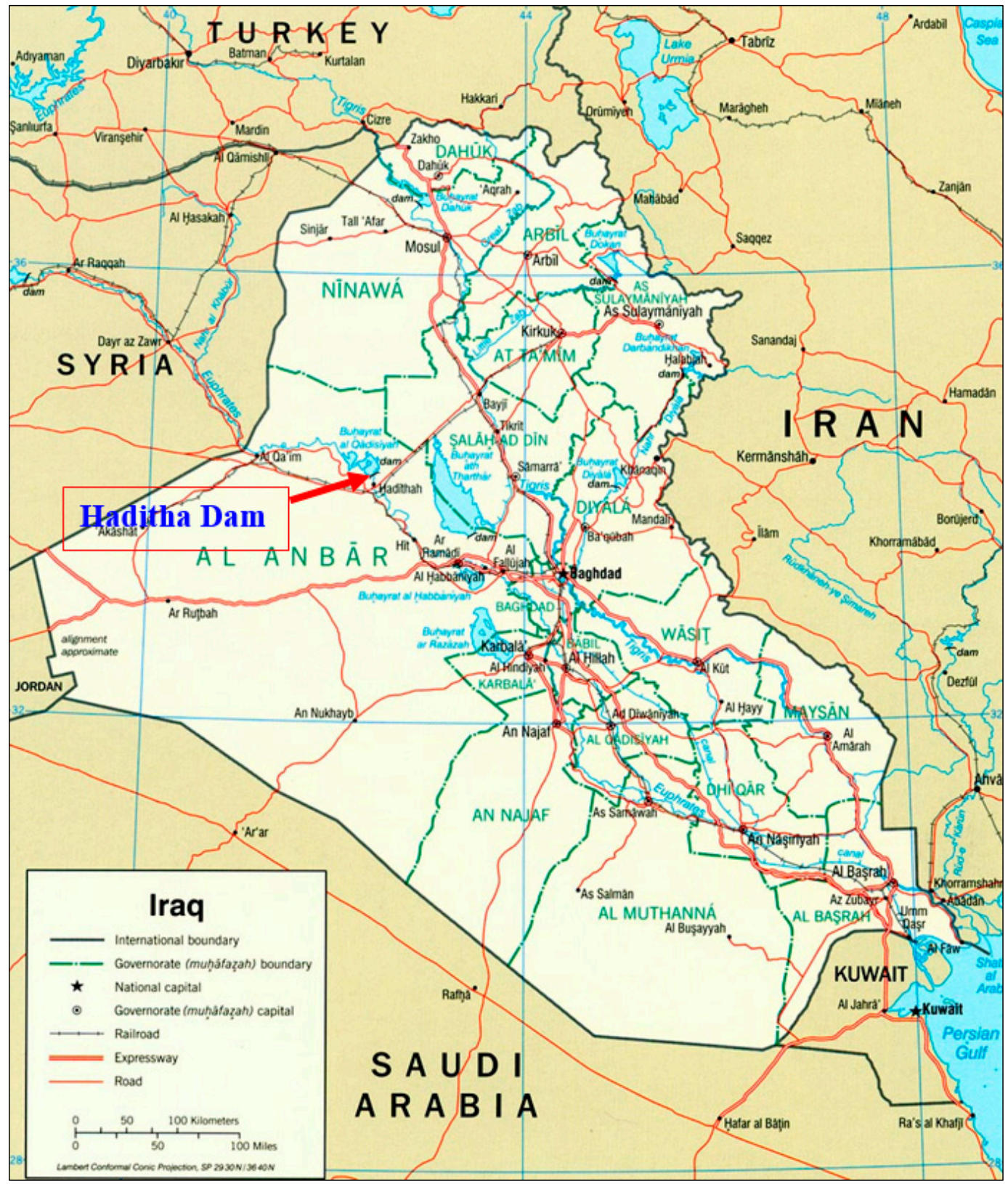

(a)

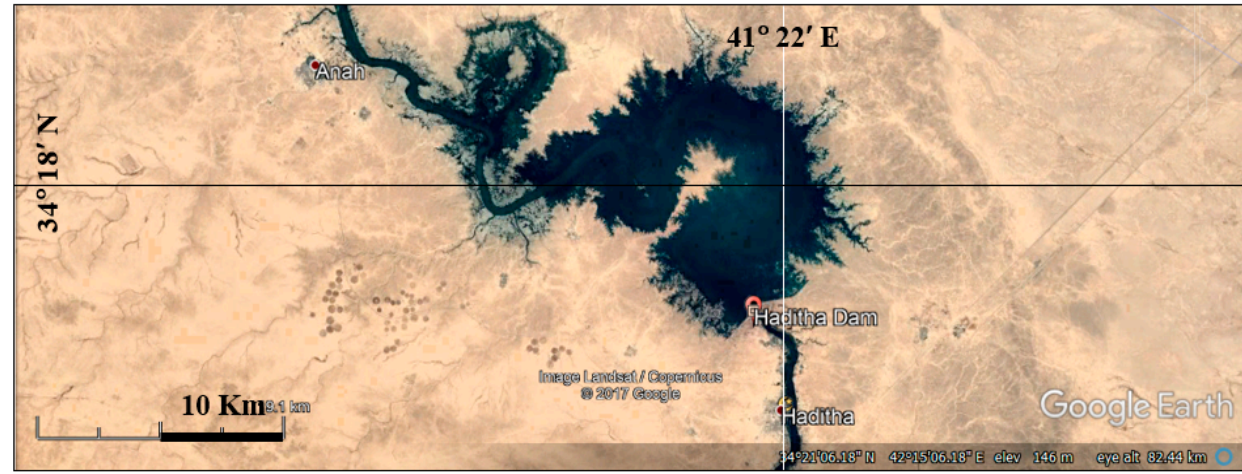

(b)

Figure 1. Cont. 


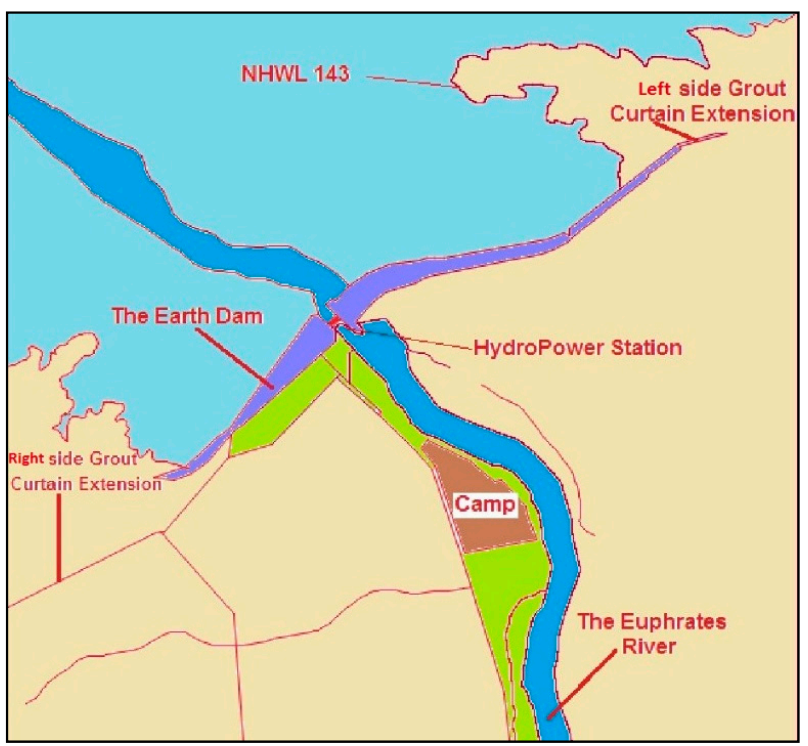

(c)

Figure 1. (a) Location map of Haditha dam on the Euphrates river, (b) Haditha dam coordinates, and (c) Haditha dam layout.

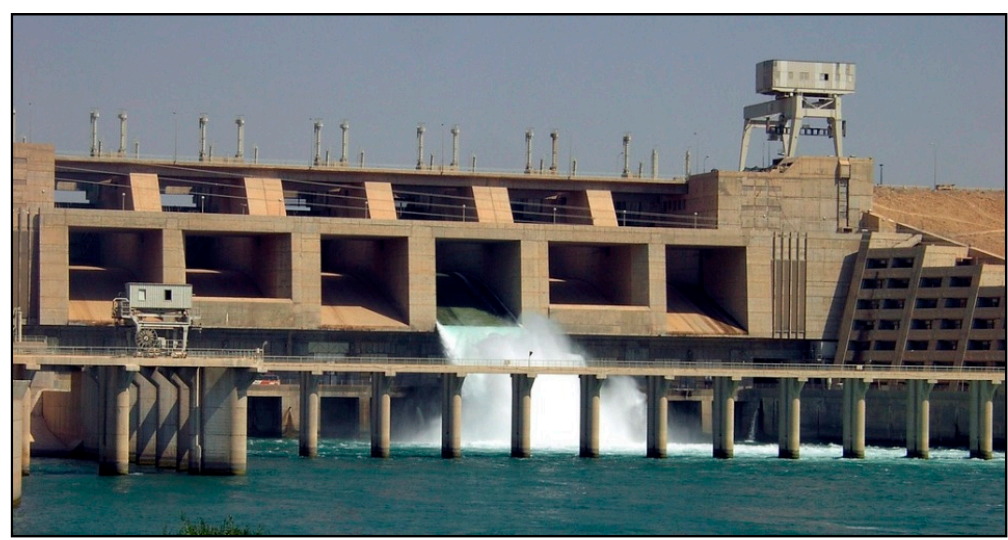

(a)

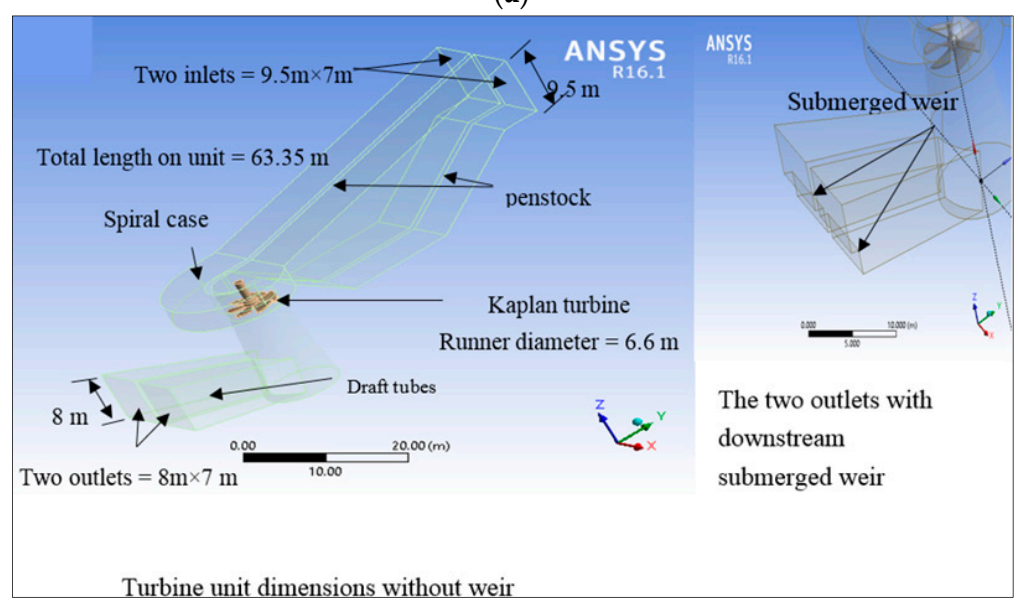

(b)

Figure 2. (a) Downstream of Haditha dam with a spillway and power station outlets, and (b) visualization of the 3-D model of the vertical Kaplan unit with full dimensional details. 


\section{3-D Finite Element Modeling}

The hydraulic structures were designed and analyzed using an approach that focuses on the affected forces on the embanked dam body, the powerhouse with the turbines, and changes in the upstream water level. In this study focuses on the dynamic analysis of hydraulic conditions was done by using FE modeling.

\subsection{Numerical Method}

Numerical analysis was conducted depending on finite element volume method by using ANSYS ${ }^{\circledR}$. This program environment was based on a continuum finite element analysis. Every derivative in the set of governing equations was replaced directly by a set of algebraic matrices written in terms of the field variables (e.g., stress, displacement) at discrete points in 3-D. The formulation of the 3-D model involves the connection of the ANSYS-static structural component, which represents 3-D Haditha earthfill dam model with the ANSYS-CFX model component, including one vertical Kaplan turbine unit of the powerhouse.

\subsection{Models Validation}

Validation of ANSYS-CFX model was conducted in two stages. In the first stage, the pressure pattern and velocity distribution in a selected turbine unit were predicted by ANSYS-CFX model and compared with the predicted values obtained from Newmark numerical method. The comparison is shown in Table 2. Data used in running the ANSYS-CFX model were adopted from [8]. In the second stage, the predicted dam stability due to the vibration effect was conducted by using the ANSYS dam-powerhouse model, and the results were compared with the forced vibration test conducted by [26] on the Masjed-Soleiman (MS) embankment dam, and the results are shown in Table 2.

Table 2. The ANSYS-CFX turbine model validation compared with the Newmark numerical method results, and the ANSYS dam model validation compared with Masjed-Soleiman (MS) embankment dam (forced vibration test).

\begin{tabular}{|c|c|c|c|c|c|}
\hline ANSYS-CFX & $\begin{array}{c}\text { Newmark } \\
\text { Numerical Method }\end{array}$ & ANSYS-CFX & $\begin{array}{c}\text { Newmark } \\
\text { Numerical Method }\end{array}$ & ANSYS & $\begin{array}{c}\text { Forced } \\
\text { Vibration Test }\end{array}$ \\
\hline $\begin{array}{l}\text { Velocity vector } \\
\mathrm{V}(\mathrm{m} / \mathrm{s})\end{array}$ & $\begin{array}{l}\text { Velocity vector } \mathrm{V}^{\prime} \\
(\mathrm{m} / \mathrm{s})\end{array}$ & $\begin{array}{c}\text { Pressure distribution } \\
\mathrm{P}(\mathrm{kPa})\end{array}$ & $\begin{array}{c}\text { Pressure distribution } \\
\mathrm{P}^{\prime}(\mathrm{kPa})\end{array}$ & $\begin{array}{l}\text { Frequency } \mathrm{f}^{\prime} \\
(\mathrm{Hz})\end{array}$ & $\begin{array}{l}\text { Frequency } \mathrm{f}^{\prime} \\
(\mathrm{Hz})\end{array}$ \\
\hline 0 & 0 & -475 & -480 & 3.58 & 3.5 \\
\hline 4.9375 & 5 & -160 & -160 & 3.91 & 3.9 \\
\hline 9.875 & 10 & 155 & 160 & 4.38 & 4.4 \\
\hline 14.8125 & 15 & 470 & 480 & 4.75 & 4.7 \\
\hline 19.75 & 20 & 785 & 800 & 6.21 & 6.1 \\
\hline 24.6875 & 25 & 1100 & 1120 & 7.02 & 6.9 \\
\hline 29.625 & 30 & 1415 & 1440 & 8.17 & 8.1 \\
\hline 34.52625 & 35 & 1730 & 1760 & & \\
\hline 39.5 & 40 & & & & \\
\hline
\end{tabular}

\subsection{Hydraulic Analysis of a 3D Numerical Modeling of One Kaplan Turbine Unit}

In this study, a vertical Kaplan turbine of the Haditha powerhouse was selected as the case study. A 3D FV numerical model was created and simulated using ANSYS-CFX to represent the turbine unit. The unit includes the runner with blades and shaft, and is defined as a submerged rotational body. The water field, which includes the inlets, penstocks, spiral case, and two draft tubes with its outlets, were also defined. Figure $2 \mathrm{~b}$ outlines the dimension details of the turbine model.

The turbine model is built in ANSYS-CFX and it is based on the finite-volume technique. The flow simulation of the Kaplan turbine was employed by using several meshes to test the grid independence, and it converges after many iterations. The grid independence of the turbine is made using tetrahedral elements after performing several trials to determine the smallest possible aspect ratio under 150 and the minimum orthogonal over 0.15 as recommended by ANSYS-CFX code. Whereas, hexahedral elements analysis performed for the wall boundary layers. To obtain the required pressure fluctuation, 
the final mesh satisfied $y^{+}<200$ around the boundary wall, and this is in agreement with the previous research conducted by [33]. The runner, guide vanes, and the draft tube interactions were counted by using slip meshes. This slipping of meshes are toured each other in the interface sides. However, it is important to ensure that the velocity components, pressure, and flow flux are harmonious after interpolation.

\subsection{3-D Numerical Modeling of the Dam-Powerhouse-Reservoir-Foundation System}

The ANSYS-static structure was used to simulate its 3D form and behavior, based on the shape of the Haditha earthfill dam, and its connection to the six turbines that represent the powerhouse, foundation, and upstream reservoir. The model used assumptions of a $57 \mathrm{~m}$ long foundation depth, and with minimum and maximum upstream water levels, as listed in Table 1. Figure 3 illustrates the 3-D model of the Haditha dam with a $57 \mathrm{~m}$ foundation base in the full reservoir case.

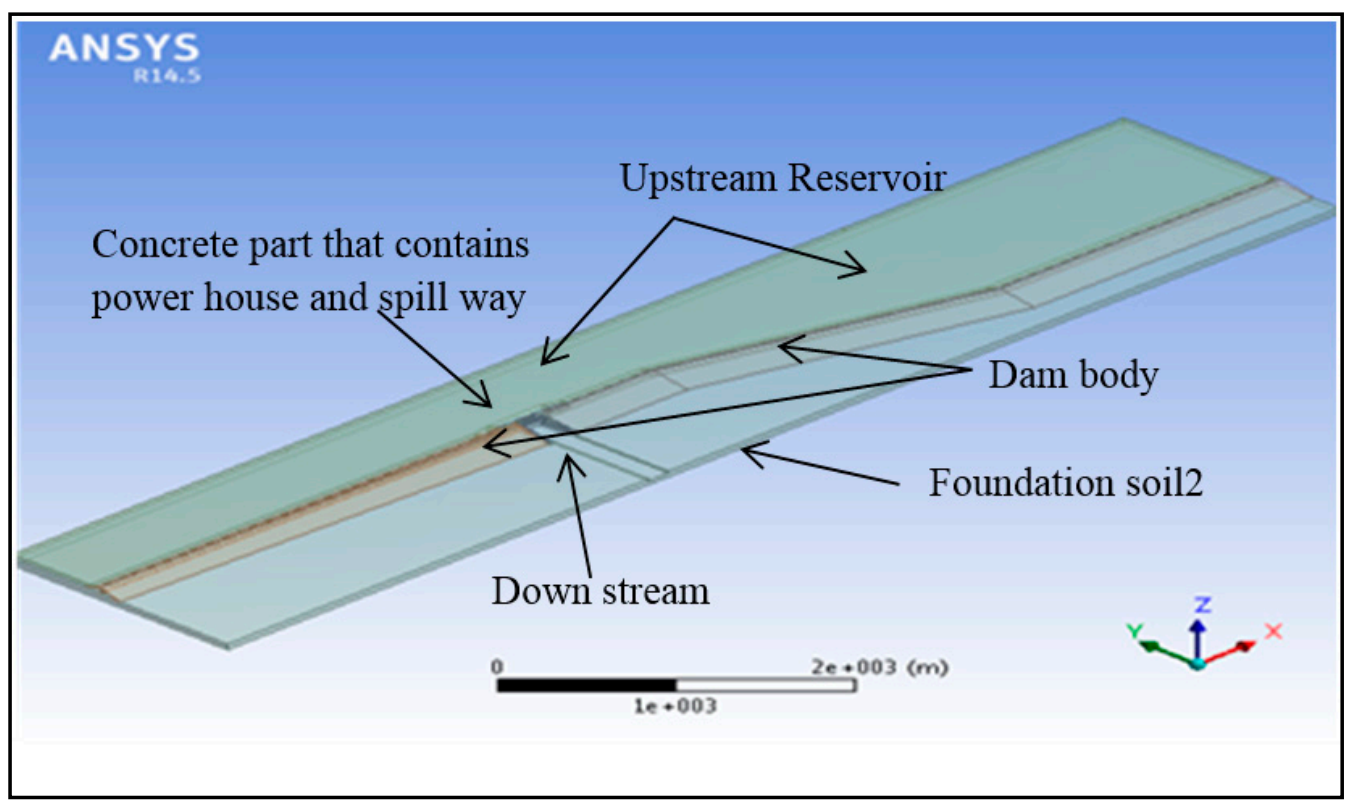

Figure 3. The dam-reservoir-foundation system of Haditha dam.

The 3-D model of the Haditha dam-powerhouse (represented by six turbine units)-foundationreservoir system was created and represented using a suitable mesh. The interface of the common area (turbine tunnel areas) interacts with different domains, such as fluid and solid domains with unique properties of dam body materials, upstream reservoir, and abutments with foundation soil. A 3D FE model used for ANSYS-static structural analysis to create the 3D Haditha dam model is described as follows [33]:

i. The 3D solid elements were used to model the earthfill dam body, foundation bed, and abutments in connection to the concrete part in the region near the turbine boundary and mesh was refined to represent the small details of the turbine boundary, as shown in Figure 4.

ii. The upstream reservoir was represented by three-dimensional fluid elements.

iii. The meshing details used in the Haditha Kaplan turbine model is shown in Table 3. 


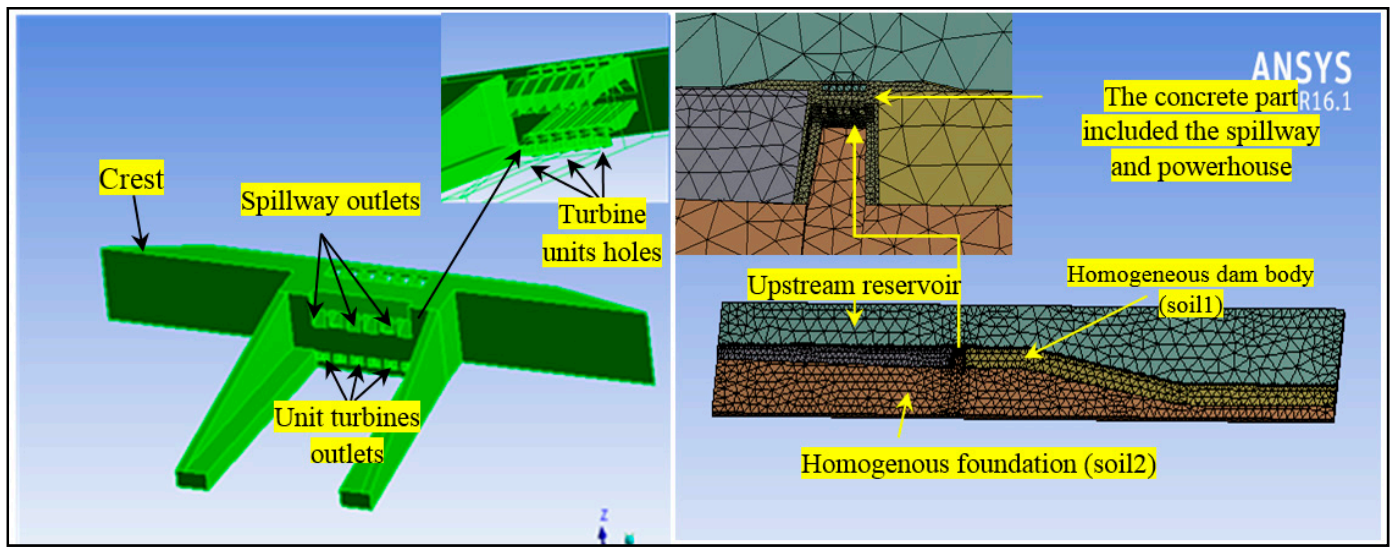

Figure 4. The concrete part of Haditha dam includes the spillway and powerhouse, and the 3-D FE model of the Haditha dam, includes the turbine units.

Table 3. The mesh details of the Haditha Kaplan turbine and dam models.

\begin{tabular}{cccccc}
\hline \multicolumn{2}{c}{ Mesh Details of Turbine and Dam Models } & Nodes & Elements & $\begin{array}{c}\text { Max. Aspect } \\
\text { Ratio }\end{array}$ & $\begin{array}{c}\text { Minimum } \\
\text { Orthogonal Quality }\end{array}$ \\
\hline $\begin{array}{c}\text { Haditha } \\
\text { Kaplan turbine }\end{array}$ & water & 9785833 & 2174630 & 10.706 & 0.23896 \\
\hline \multirow{4}{*}{ Haditha dam } & 1808946 & 401988 & 10.706 & 0.23896 \\
\hline & foundation & 1596798 & 967068 & & \\
& water & 572656 & 315930 & & \\
& Left embankment side & 396880 & 224558 & & \\
& Right embankment side & 126394 & 71282 & & \\
& Concrete part includes & 1842786 & 1215094 & & \\
\hline
\end{tabular}

\section{Application Results and Discussion}

The results obtained from the application of the 3-D FE numerical model for the Haditha embankment dam integrated with the turbine model can be categorized into two summarized stages as listed below:

(1) The first stage of the hydraulic performance results is related to the application of the 3-D numerical finite volume turbine model by considering the operation of one vertical Kaplan turbine unit in the powerhouse of the Haditha dam that runs in different water levels and discharge ranges. The results include velocity flow lines, pressure distribution in the turbines, and a total estimated head at the turbine inlet compared with the upstream water level.

(2) The second stage of the results is that obtained from the integration of 3-D numerical finite element dam models with 3-D numerical finite volume turbine models. The results cover all the possibilities that may arise from the operation of the powerhouses, including maximum and minimum water levels for the case of full inlet gates openings. The results of the 3-D dam models include principal stresses distributions in both dams and powerhouses.

\subsection{Turbine Model Simulations}

The $\mathrm{k}-\varepsilon$ turbulence 3D model and the finite volume method were used to distinguish the unsteady flow inside the Kaplan turbine unit. Input data (upstream water levels with discharges) used by the model were obtained from engineering reports and the dam site visits. The maximum drawdown and flood upstream water level with varying discharges, gravity weight, and the speed of the turbine were also considered. Table 4 outlines the hydraulic data of the Haditha powerhouse used in running the turbine model. 
Table 4. Hydraulic data of the Haditha powerhouse turbine, including up-stream water levels (U/S.W. $\mathrm{L})$, the flowrate $(\mathrm{Q})$, the velocity $(\mathrm{V})$, and the rotational speed of the turbine runner $(\mathrm{N})$.

\begin{tabular}{|c|c|c|c|c|c|c|}
\hline No. & U/S.W. L (m) & Net Head (m) & $\mathbf{N}_{\mathrm{QE}}$ & $\mathrm{Q}\left(\mathrm{m}^{3} / \mathrm{s}\right)$ & $\mathrm{V}_{\text {einlet }}(\mathrm{m} / \mathrm{s})$ & $N(\mathrm{rad} / \mathrm{s})$ \\
\hline \multicolumn{7}{|c|}{ Haditha Turbine } \\
\hline 1 & 129 & 18.5 & 0.6779 & 100 & 1.5038 & 3.3520 \\
\hline 2 & 134.3 & 25.5 & 0.5800 & 118 & 1.7744 & 3.3586 \\
\hline 3 & 139.6 & 32.5 & 0.5155 & 136 & 2.0451 & 3.3353 \\
\hline 4 & 144.9 & 39.5 & 0.4689 & 151 & 2.2707 & 3.3326 \\
\hline 5 & 150.2 & 46.5 & 0.4331 & 169.5 & 2.5489 & 3.2839 \\
\hline
\end{tabular}

The boundary conditions for the steady flow computation are as follows. The 3D numerical model runs by inputting the inlet velocity that is calculated from the actual discharges listed in Table 4. The speed of the turbines is shown in Table 4 . The outlet pressure was taken to be equal to ( 1 bar) according to the downstream water level. Also, the rotational speed of the turbine runner was defined. The turbine runner with a shaft was defined in the turbine model as a rotational body about its centroidal axis.

The results of the steady flow calculations were taken as the initial flow field for the complete unsteady flow passage. A time step of $0.001 \mathrm{~s}$ and runner rotating speeds of 3.352 and $3.2839 \mathrm{rad} / \mathrm{s}$ were chosen for the minimum and maximum upstream water levels shown in Table 2. For each time step, the turbine runner will rotate with angles of $1.53^{\circ}$ and $1.5^{\circ}$, but for total time steps of 5000 , the turbine runner should rotate by more than one cycle.

The reaction turbines represent one of the largest hydraulic structures. Water pressure applies force on the runner blades, and this pressure decreases throughout a running turbine; this phenomenon is presented in both the Francis and Kaplan turbines. The runner and the blades of the turbines are fully immersed in water, and they must be sufficiently strong to resist the operating pressure. The generated electric power of the turbine units is given in Formula (1) [34,35]:

$$
P=\rho \cdot Q \cdot g \cdot H \cdot \eta
$$

where $P$ is the generated electric power(watt), $\rho$ is the water mass density $\left(\mathrm{kg} / \mathrm{m}^{3}\right), Q$ is water discharge $\left(\mathrm{m}^{3} / \mathrm{s}\right), g$ is the acceleration due to gravity $\left(9.81 \mathrm{~m} / \mathrm{s}^{2}\right), H$ is the water head $(\mathrm{m})$, and $\eta$ is the efficiency of the hydropower.

The energy of the turbines $E$ is defined as can be seen in Equation (2) [36]:

$$
E=g \cdot H_{t}=\left(\frac{p_{1}-p_{2}}{\rho}\right)+\left(\frac{V_{1}^{2}-V_{2}^{2}}{2}\right)+g \cdot\left(z_{1}-z_{2}\right)+g \cdot \text { head } \text { loss }_{1-2}
$$

where $H_{t}$ is the water head of turbine $(\mathrm{m}), g$ is the acceleration gravity $\left(9.81 \mathrm{~m} / \mathrm{s}^{2}\right), p_{1}$ is the upstream pressure (pa), $p_{2}$ is the downstream pressure (pa), $V_{1}$ is the upstream velocity (m/s), $V_{2}$ is the downstream velocity $(\mathrm{m} / \mathrm{s}), z_{1}$ is the upstream elevation $(\mathrm{m})$, and $z_{2}$ is the downstream elevation (m). Sections 1 and 2 are defined as the upstream and downstream measurements of the turbine, respectively. The determined behavior of the hydraulic turbine models is based on a dimensional analysis. Laboratory developments and model tests can guarantee the hydraulic behavior and the turbine efficiency (Iryo and Rowe 2003). The International Electrotechnical Commission standards 60193 and 60041 define all the simulation rules [37,38]. The specific speed of a turbine based on these standards is defined in the following formula [35,39]:

$$
n_{Q E}=\frac{n \cdot \sqrt{Q}}{\left(g H_{n}\right)^{\frac{3}{4}}}
$$


where $n$ is the rotational speed of turbine runner, and $H_{n}$ is the net head of the turbine. The parameter $n_{Q E}$ is known as the specific speed, which is a general relationship that combines the main parameters governing geometrically similar turbines operating under dynamic conditions.

Numerous statistical studies on reaction turbines have established a correlation between the speed and net head for each type of turbine. The Schweiger and Gregory correlation formulae for Kaplan turbines are defined as [40]:

$$
n_{Q E}=\frac{2.294}{H_{n}{ }^{0.486}}
$$

Table 5 shows the inlet total head results obtained by running the turbine model at different speeds (shown in Table 4), for each of the five trails where upstream water levels were different. The inlet head calculations were then used to evaluate the inlet pressure that provides the total head at penstock inlet closest to the upstream water level.

Table 5. Total head with the percent of error calculation at the inlet of the Haditha turbine unit.

\begin{tabular}{|c|c|c|c|c|c|c|c|c|}
\hline No. & U/S.W. L (m) & $\mathrm{Q}\left(\mathrm{m}^{3} / \mathrm{s}\right)$ & $\mathrm{V}_{\text {inlet }}(\mathrm{m} / \mathrm{s})$ & $\mathrm{v}^{2} / 2 \mathrm{~g}(\mathrm{~m})$ & $\mathrm{p} / \gamma(\mathrm{m})$ & $\mathrm{Z}(\mathrm{m})$ & $E_{\text {inlet }}=v^{2} / 2 g+p / \gamma+Z$ & Error \% \\
\hline 1 & 129 & 100 & 1.5038 & 0.12 & 23.71 & 105.25 & 129.08 & 0.06 \\
\hline 2 & 134.3 & 118 & 1.7744 & 0.16 & 28.98 & 105.25 & 134.39 & 0.07 \\
\hline 3 & 139.6 & 136 & 2.0451 & 0.21 & 34.47 & 105.25 & 139.93 & 0.24 \\
\hline 4 & 144.9 & 151 & 2.2707 & 0.26 & 37.54 & 105.25 & 143.06 & 1.27 \\
\hline 5 & 150.2 & 169.5 & 2.5489 & 0.33 & 46.22 & 105.25 & 151.80 & 1.06 \\
\hline
\end{tabular}

Note: ${ }^{2} / 2 \mathrm{~g}$ is the velocity head at the inlet of turbine, $\mathrm{p} / \gamma$ is the pressure head at the turbine inlet, $\mathrm{Z}$ in the average elevation head at the turbine inlet, and $\mathrm{E}_{\text {inlet }}$ is the total head calculated at the turbine inlet.

The differences between the upstream water levels and the total inlet head evaluated by operating the turbine model at five water levels are listed in Table 4 . The results outlined that the maximum difference between the upstream water level and total head estimated at the inlet of Haditha turbine model was equal to $1.83 \mathrm{~m}$, which was equivalent to the maximum relative error of $1.27 \%$. The head loss varies according to the type of flow that is classified depending on the Reynolds number and the types of pipes (smooth or rough), indicating that there is no unique value for head loss in the turbulent. The rotational turbine speed also varies according to the gross head and discharge obtained from the dam site visit.

The velocity distribution along the penstock of turbine model unit varied with a change in cross-sectional area. Meanwhile, based on the continuity equation, the velocity gradually increased from the spiral case to the turbine runner, based on the cross-sectional area. The velocity flow lines followed a spiral shape in the draft tube because of the rotational motion of the turbine runner. Figure 5a illustrates the velocity flow lines inside the unit of Haditha Kaplan turbine. The results show that the maximum flow velocity occurred at the runner region, and it was found to be $50 \mathrm{~m} / \mathrm{s}$ at the $150.2 \mathrm{~m}$ upstream water level.

The distribution of the boundary pressure in the units of the Haditha turbine are shown in Figure $5 \mathrm{~b}$. This represents the case of the turbine running under the maximum upstream water level. The results showed that pressure distribution was proportional to the inverse of velocity, and this was in line with the energy equation. However, the drop-in pressure occurring in the turbine shaft was greater than the cavitation pressure. The pressure distribution and velocity flow lines were in agreement with that found in the literature [38]. 


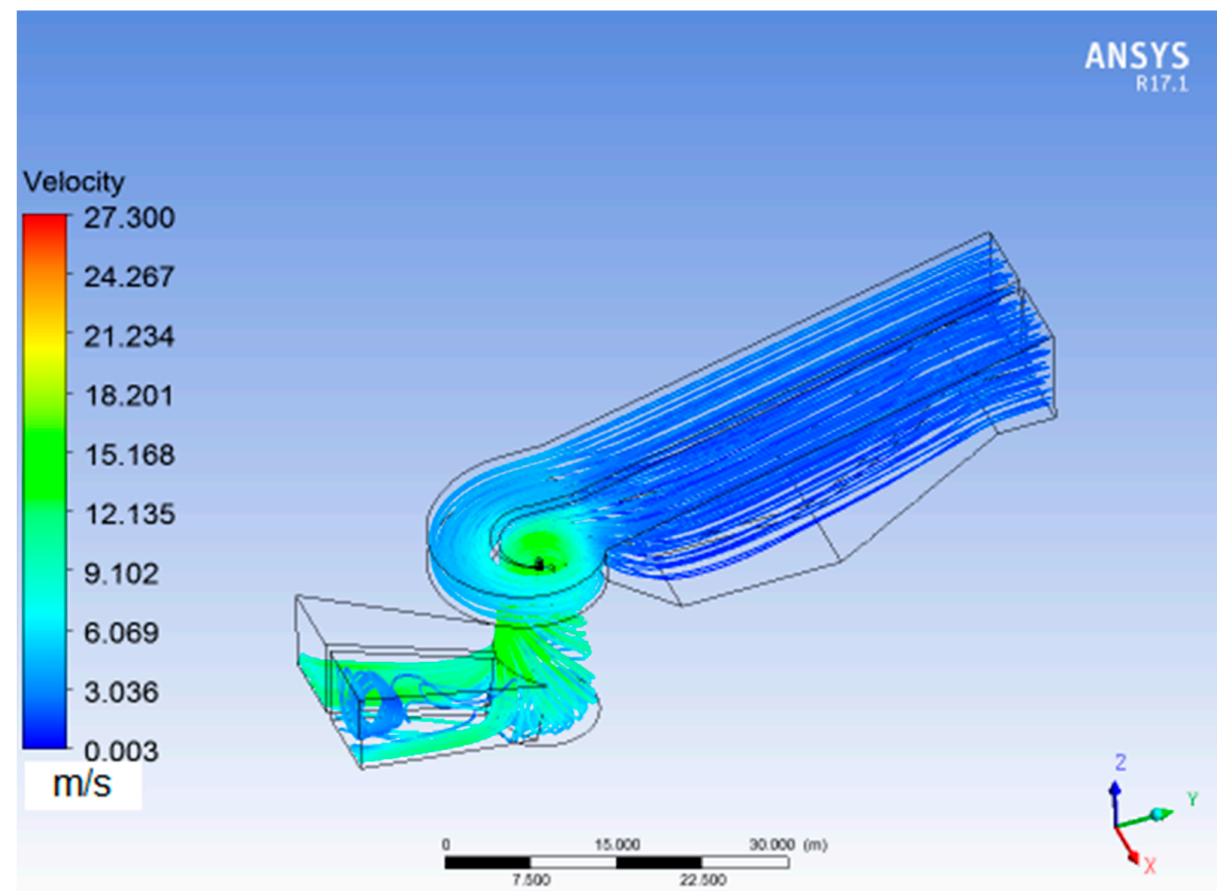

(a)

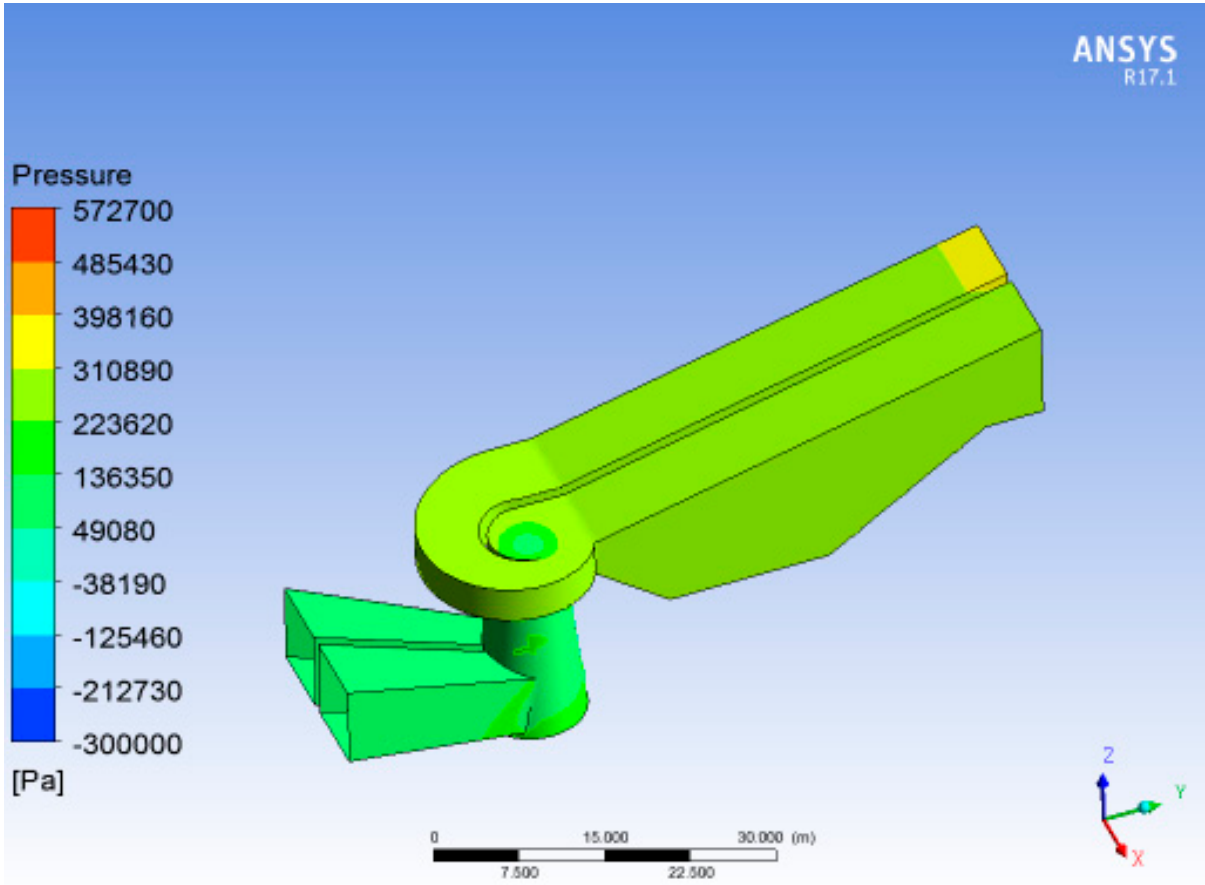

(b)

Figure 5. Example of the graphical presentation of (a) the velocity flow lines and (b) the pressure distribution in the Haditha turbine unit.

\subsection{Dynamic Analysis Results of the Dam Model Connected with the Turbine Model}

The actual stress situation in the body of the dam is complex, and it may differ from the calculated stress during the design stage. The differences may be too high and they may lead to extensive dam 
damage. This inconsistency can be attributed to the construction process, thermal stress during the construction and operating period, water pressure in the reservoir, penetration of turbine outlets in dam body, base deformation, or connections and differences between the actual values and predicted values of the mechanical and thermal properties of the materials. A comprehensive exploration of the hydropower plant operation was conducted in order to reduce the principal stress on the dam structure. Finite element computation and analysis was developed to investigate the optimal hydropower running with sustained long life for the earthfill dam by focusing on Haditah dam in Iraq as a case study.

The dam model was created to evaluate the principal stresses of the dam-turbine-reservoir foundation system with changing water levels from the maximum drawdown to the flood level. The fluid-solid connection, hydrostatic pressure, and gravity were defined. The latter was determined according to the water level and the foundation depths.

Figure 6 shows the ANSYS software GUI options (connection between CFX and STATIC STRUCTURAL parts), and Figure 7 illustrates the ANSYS-CFX solution that represents the 3D turbine model, and its connection with the ANSYS-static structural setup that represents the Haditha dam model. The holes in the structural model stand for the six turbine locations. This framework was used to transform the results of turbine model for the boundary-pressure pattern to the common area between the dam body and six holes that represent the turbine unit locations at the same water level.

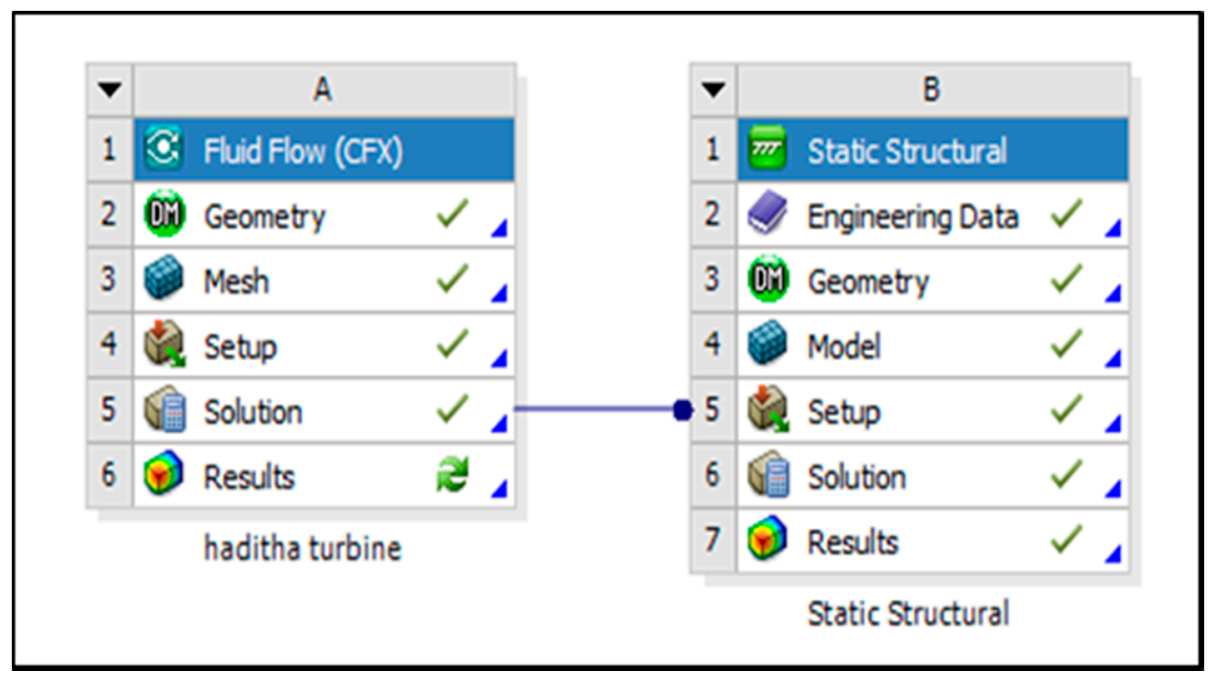

Figure 6. The connection between the ANSYS-CFX solution and the STATIC-STRUCTURAL setup.

The dam with turbine framework was run for maximum drawdown and flood upstream water levels, after considering all possibilities of the turbines operation (single, two, three, four, five, or six units) that minimizes the principal stresses in selected points of the dam body (as outlined in Figure 7a). The results and technique applied for the Haditha dam are compared with the related corresponding results. 


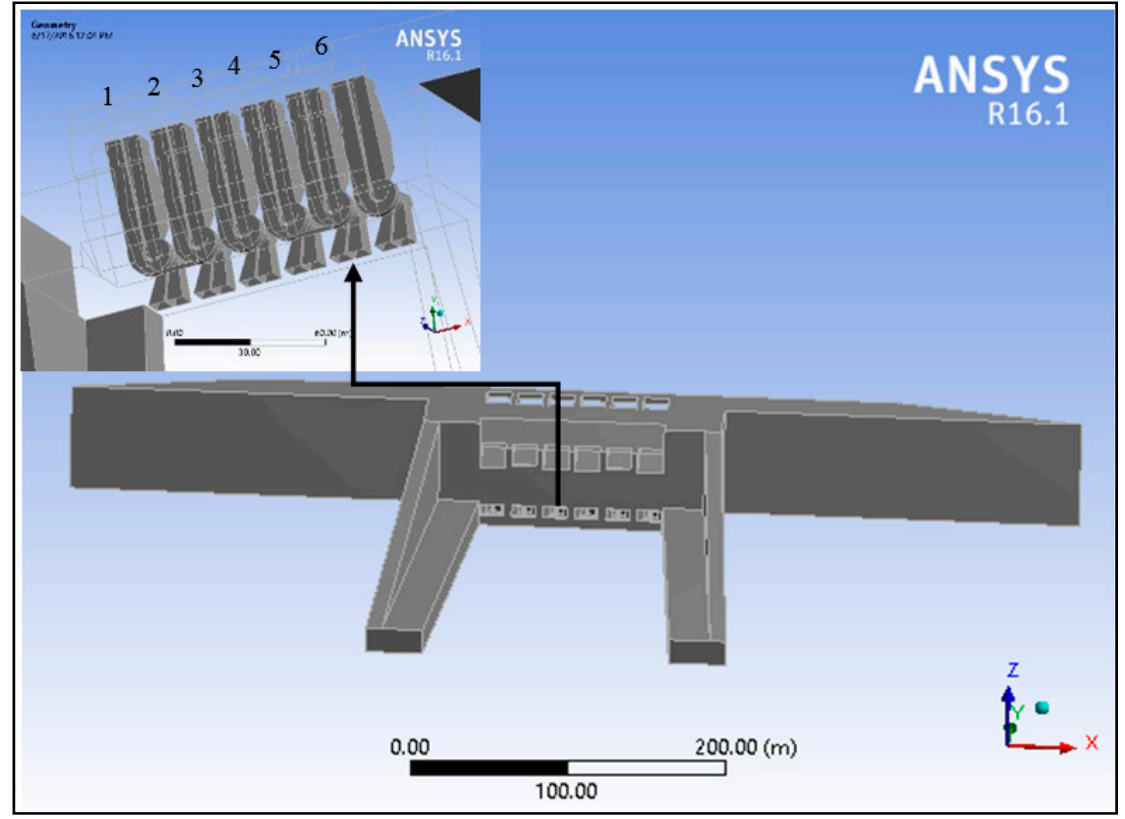

(a)

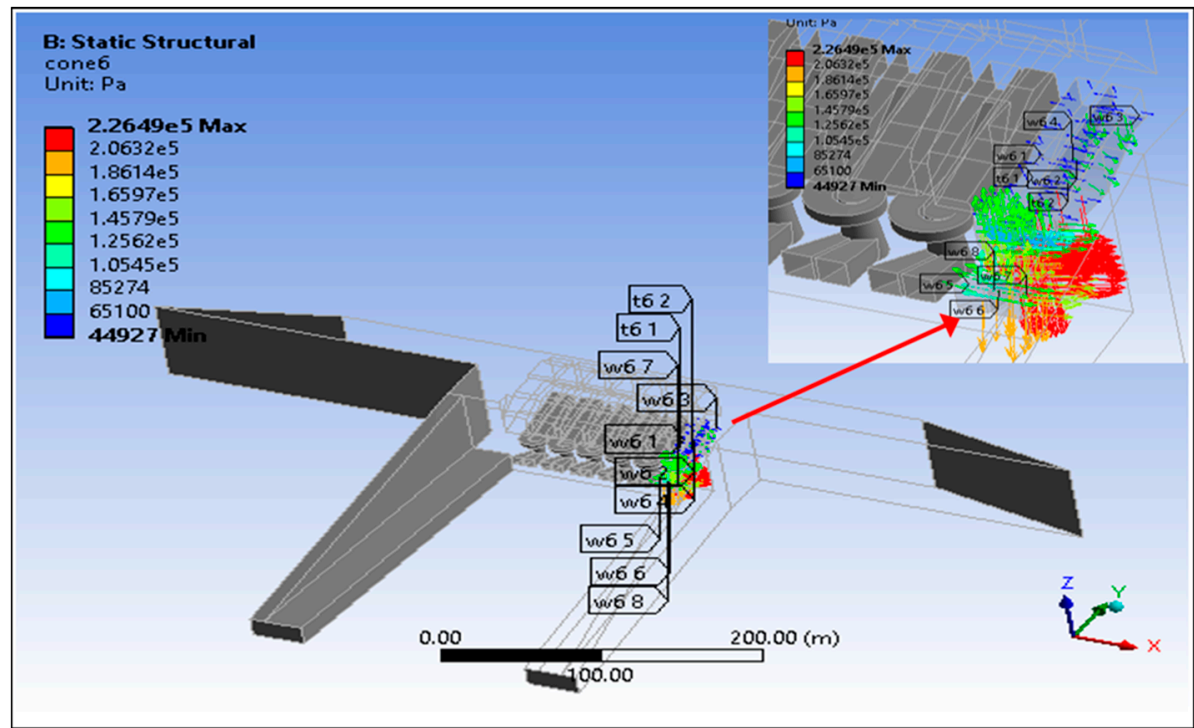

(b)

Figure 7. (a) The concrete part of Haditha dam with numbering the turbines and (b) the 3-D numerical model transforming the pressure pattern from the Haditha turbine model to the boundary of turbine unit number 6 .

Figure $7 \mathrm{~b}$ illustrates the concrete part of the Haditha dam model with six holes, representing the region of the turbine units and the pressure pattern on one turbine hole, which was transformed from the 3D turbine model. The results show that the pressure is gradually decreased from the unit inlet to the unit outlet. This decrease includes friction losses that are governed by the energy equation.

Figure 8 shows the pattern of maximum principal stress at the selected nodes of the turbine concrete part when the turbine units are operating under full loading case. In order to cover all the possibilities of running the six turbines inside the powerhouse, the patterns of boundary pressure of Haditha dam with one Kaplan turbine framework were imported from the ANSYS-CFX turbine mode that was run 130 times (65 times with the flood upstream water level and 65 times with maximum drawdown upstream water level). 


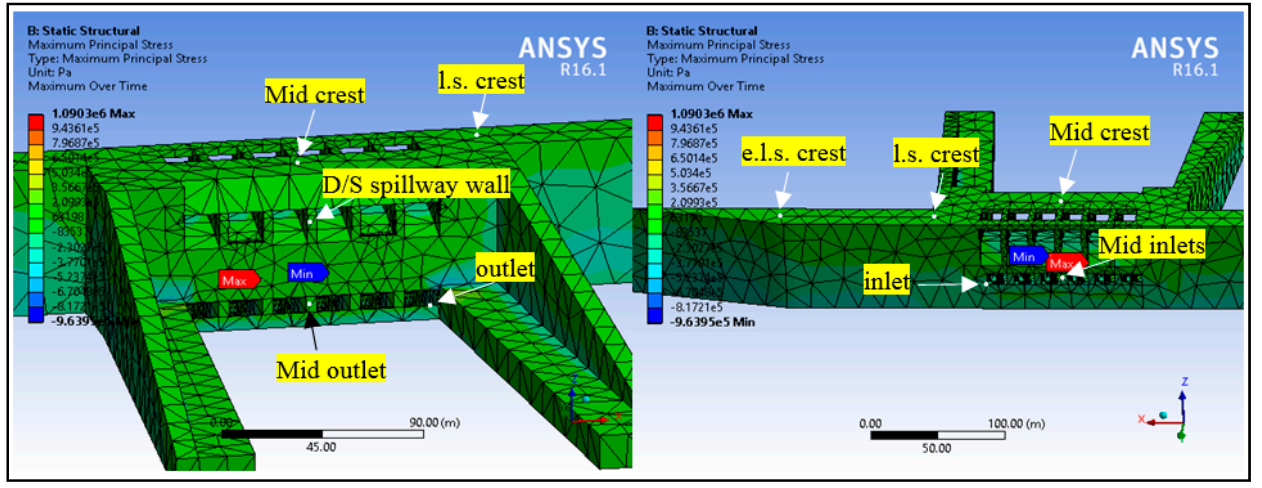

Figure 8. The selected points to measure the principal stress and its distribution in the concrete part of Haditha dam in maximum drawdown with six turbines operating.

In this study, the six turbines in the power house of Haditha dam were numbered 1, 2, 3, 4, 5, and 6 (Figure 8). Figure 8 shows the critical points on the Haditha dam body, while Figure 9 shows the values of the maximum principal stresses at these points. The stresses resulted from the combined operation of any of the three turbines. The maximum value of the principal stress was found to be $1400.8 \mathrm{kPa}$, and it occurred on the region combining the turbine shaft with the outlet. A total of 130 turbine operation scenarios were conducted in order to determine the operation scenario that could give the minimum principal stress.

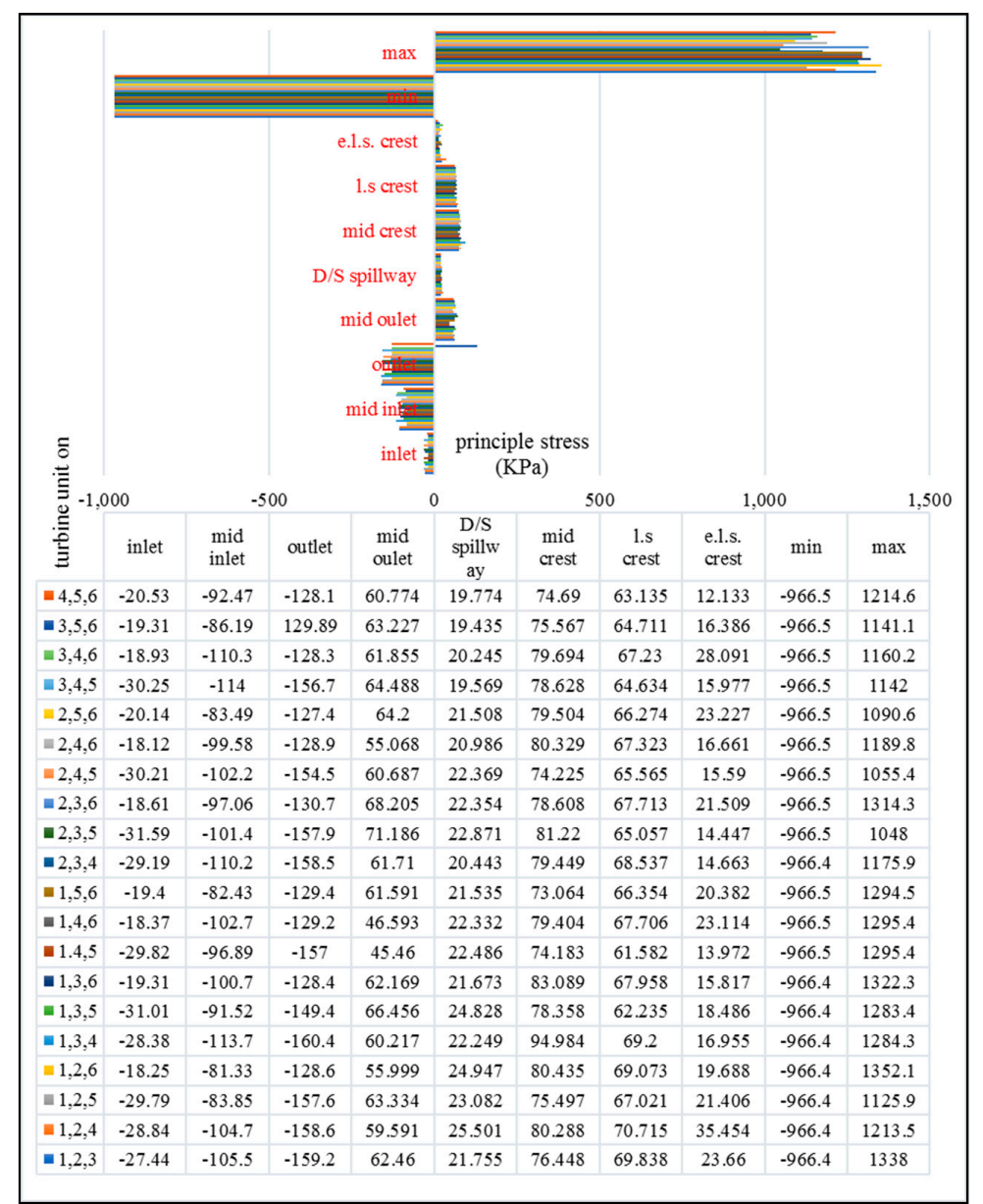

Figure 9. The principal stress values in the selected points of the Haditha dam body due to running three turbine units at a maximum upstream water level. 
Table 6 indicates that the turbines' operations had minimal effect on the values of minimum principal stress. This was attributed to the distance from the minimum stress region to the turbine locations. The percentage of the change of these values in the maximum drawdown and flood water levels were equal to $0.01 \%$ and $0.03 \%$, respectively. Based on the fluctuation of the pressure values, the points in the base of the cone and the draft tube near the outlet of powerhouse were mostly affected by the turbines' operation. For the various operation scenarios, the maximum difference in the principal stress due for the maximum water level was found to be $352.8 \mathrm{kPa}$, whereas it was $225 \mathrm{kPa}$ for the minimum water level.

Table 6. Statistical analysis of the principal stress results of the Haditha dam according to the running turbines at maximum and minimum upstream water levels.

\begin{tabular}{|c|c|c|c|c|c|c|c|c|c|c|}
\hline $\begin{array}{c}\text { Minimum Water } \\
\text { Level }\end{array}$ & Inlet & Mid Inlet & Outlet & $\begin{array}{l}\text { Mid } \\
\text { Outlet }\end{array}$ & $\begin{array}{c}\text { D/S } \\
\text { Spillway }\end{array}$ & $\begin{array}{l}\text { mid } \\
\text { Crest }\end{array}$ & 1.s Crest & e.l.s. Crest & Min & Max \\
\hline Maximum (kPa) & -181 & -103 & -83 & 67 & 39 & 79.2 & 25.9 & 41 & -963 & 1311 \\
\hline Minimum (kPa) & -215 & -184 & -138 & 41 & 20 & 70.0 & 20.1 & 21 & -964 & 1086 \\
\hline Difference (kPa) & 33.7 & 81.1 & 55 & 26 & 18 & 9.2 & 5.8 & 20 & 0.1 & 225 \\
\hline Percent (\%) & 18.54 & 78.49 & 66 & 38 & 47 & 11 & 22 & 49 & 0.01 & 17 \\
\hline $\begin{array}{c}\text { Maximum Water } \\
\text { Level }\end{array}$ & Inlet & Mid Inlet & Outlet & $\begin{array}{c}\text { Mid } \\
\text { Outlet }\end{array}$ & $\begin{array}{c}\text { D/S } \\
\text { Spillway }\end{array}$ & $\begin{array}{l}\text { mid } \\
\text { Crest }\end{array}$ & 1.s Crest & e.l.s. Crest & Min & Max \\
\hline Maximum (kPa) & -17 & -68 & -121 & 80 & 29 & 95 & 77 & 35 & -966 & 1400.8 \\
\hline Minimum (kPa) & -39 & -125 & -160 & 45 & 18 & 73 & 56 & 9 & -966 & 1048.0 \\
\hline Difference (kPa) & 21 & 56 & 38 & 34 & 10 & 21 & 20 & 26 & 0.3 & 352.8 \\
\hline Percent $(\%)$ & 125 & 81 & 31 & 43 & 37 & 23 & 27 & 74 & 0.03 & 25.19 \\
\hline
\end{tabular}

Table 7 shows the ranges of principal stresses associated with the best combination of turbine operation. Four colors were used to show the ranges of the principal stresses from minimum maximum and these colors are blue, green, yellow, and red.

Table 7. Haditha principal stress classification.

\begin{tabular}{ccc}
\hline Principal Stress Range (kPa) & Ranking & Indicator \\
\hline $1000 \leq \sigma_{\max }<1100$ & Excellent & \\
$1100 \leq \sigma_{\max }<1200$ & Good & \\
$1200 \leq \sigma_{\max }<1300$ & Acceptable & \\
$1300 \leq \sigma_{\max }<1400$ & Not acceptable & \\
\hline
\end{tabular}

Note: $\sigma_{\max }$ is the maximum Principal stress.

Figure 10 shows the number and location of the operated turbines. The total operation scenarios were 130 ( 65 operation scenarios based on the maximum reservoir water level and another 56 operation scenarios based on the minimum reservoir water level). The best operation scenario is highlighted in blue, as shown in Figure 10. 


\begin{tabular}{|c|c|c|c|c|c|c|c|c|c|}
\hline & 1.2 & 1.2 .3 & $1,2,3,4$ & $1,2,3,4,5$ & - & 1,2 & $1,2,3$ & $1,2,3,4$ & $1,2,3,4,5$ \\
\hline 1 & 1.3 & $1,2,4$ & $1,2,3,5$ & $1,2,3,4,6$ & 1 & 1,3 & $1,2,4$ & $1,2,3,5$ & $1,2,3,4,6$ \\
\hline 2 & 1,4 & $1,2,5$ & 1.2 .3 .6 & $1,2,3,5,6$ & 2 & 1,4 & $1,2,5$ & $1,2,3,6$ & $1,2,3,5,6$ \\
\hline 3 & 1,5 & 1.2 .6 & $1,2,4,5$ & $1,2,4,5,6$ & 3 & 1,5 & $1,2,6$ & $1,2,4,5$ & $1,2,4,5,6$ \\
\hline 4 & 1.6 & $1,3,4$ & $1,2,4,6$ & $1,3,4,5,6$ & 4 & 1,6 & $1,3,4$ & $1,2,4,6$ & $1,3,4,5,6$ \\
\hline 5 & 2,3 & $1,3,5$ & $1,2,5,6$ & $2,3,4,5,6$ & 5 & 2,3 & $1,3,5$ & $1,2,5,6$ & $2,3,4,5,6$ \\
\hline 6 & 2,4 & $1.3,6$ & $1,3,4,5$ & $1,2,3,4,5,6$ & 6 & 2,4 & $1,3,6$ & $1,3,4,5$ & $1,2,3,4,5,6$ \\
\hline & 2,5 & $1.4,5$ & $1,3,4,6$ & & & 2,5 & $1.4,5$ & $1,3,4,6$ & \\
\hline & 2.6 & $1,4,6$ & $1,3,5,6$ & & & 2,6 & $1,4,6$ & $1,3,5,6$ & \\
\hline & 3,4 & $1,5,6$ & $1,4,5,6$ & & & 3,4 & $1,5,6$ & $1,4,5,6$ & \\
\hline & 3,5 & $2,3,4$ & $2,3,4,5$ & & & 3,5 & $2,3,4$ & $2,3,4,5$ & \\
\hline & 3,6 & $2,3,5$ & $2,3,4,6$ & & & 3,6 & $2,3,5$ & $2,3,4,6$ & \\
\hline & 4,5 & $2,3,6$ & $2,3,5,6$ & & & 4.5 & $2,3,6$ & $2,3,5,6$ & \\
\hline & 4,6 & $2,4,5$ & $2,4,5,6$ & & & 4.6 & $2,4,5$ & $2,4,5,6$ & \\
\hline & 5,6 & $2,4,6$ & $3,4,5,6$ & & & 5.6 & $2,4,6$ & $3,4,5,6$ & \\
\hline & & $2,5,6$ & & & & & $2,5,6$ & & \\
\hline & & $3,4,5$ & & & & & $3,4,5$ & & \\
\hline & & $3,4,6$ & & & & & $3,4,6$ & & \\
\hline & & $3,5,6$ & & & & & $3,5,6$ & & \\
\hline & & $4,5,6$ & & & & & $4,5.6$ & & \\
\hline \multicolumn{5}{|c|}{$\begin{array}{l}\text { a) Turbine units on in maximum upstream } \\
\text { water level }\end{array}$} & \multicolumn{5}{|c|}{$\begin{array}{l}\text { b) Turbine units on in minimum upstream } \\
\text { water level }\end{array}$} \\
\hline
\end{tabular}

Figure 10. Control program for the running turbines in the Haditha powerhouse based on minimizing the principal stress.

The results from this study can help to understand the impact of the operation strategies on the load variations and the lifetime of the equipment of the hydropower plant. Therefore, the topics debated in this paper were more relevant and beneficial for research on dam engineering.

\section{Conclusions}

The efficiency of the powerhouse system is highly significant for dam stability and sustainability. Studying the seismic loading on the dam body in addition to the draft tube reaction turbine efficiency is extremely important for hydraulic and water resource engineering prospectives. The Draft tube is one of the essential components of the powerhouse system located downstream of the reaction turbines. The main goal of this draft tube is to convert the high impacted kinetic energy at the turbine runner outlet into pressure energy as gradually as possible. However, the constructed draft tube may initiate turbulent flows and pressure fluctuations during operation, and hence solving this problem is extremely significant for the sustainability of the dam body. This research provided a detailed analysis on the characteristics of the vertical Kaplan turbine influenced by changing water levels and discharge ranges. A case study located on the Euphrates river (i.e., Haditha dam) was selected for this work. Based on the analysis undertaken, several insights can be highlighted as follows:

i. Operation of the 3-D turbine model under various upstream water levels and discharge ranges enables a detailed analysis of the hydraulic characteristics of the reaction (Kaplan) turbines by evaluating the pressure pattern and velocity flowline distribution inside the turbine unit. A comparison of the total inlet head evaluated from running the turbine model with the upstream water level is used to validate the simulation from the turbine model.

ii. The stress fluctuation in the dam body is proportional to the distance from the turbine region. Therefore, building the powerhouse as an integral part of the dam is more efficient than using a separate powerhouse. However, this condition affects the stress fluctuations, due to powerhouse operation on the dam body. 
iii. Running turbines had an insignificant effect on the values of the minimum principal stress. This is because the distance between the turbines is far from the region of the minimum stress value.

iv. Due to the turbine running and fluctuations in principal stresses, the cone and outlet of the turbine unit of the powerhouse are the most affected regions.

v. Increasing the turbine outlet elevation with regard to the turbine blade elevations protects the turbine unit from cavitation.

vi. Applying the control program for operating the six turbines in the powerhouse of Haditha dam shows that the minimum principal stresses can be obtained, and the operation scenario can increase the life time of Haditha dam-powerhouse-foundation system.

Author Contributions: Conceptualization, A.M.S.A.; Methodology, A.M.S.A.; Software, A.M.S.A.; Validation, A.M.S.A.; Formal Analysis, N.A.-A. and J.L.; Investigation, Z.M.Y.; Resources, Z.M.Y.; Data Curation, A.M.S.A.; Writing-Original Draft Preparation, Z.M.Y.; Writing-Review \& Editing, T.A.M. and J.L.; Visualization, N.A.-A.; Supervision, T.A.M. and N.A.-A.

Funding: This research received no external funding.

Conflicts of Interest: The authors declare no conflict of interest.

\section{References}

1. Lessard, J.; Murray Hicks, D.; Snelder, T.H.; Arscott, D.B.; Larned, S.T.; Booker, D.; Suren, A.M. Dam design can impede adaptive management of environmental flows: A case study from the Opuha Dam, New Zealand. Environ. Manag. 2013, 51, 459-473. [CrossRef] [PubMed]

2. Aydan, Ö.; Uehara, F.; Kawamoto, T. Numerical Study of the Long-Term Performance of an Underground Powerhouse Subjected to Varying Initial Stress States, Cyclic Water Heads, and Temperature Variations. ASCE Int. J. Geomech. 2012, 12, 14-26. [CrossRef]

3. Caetano de Souza, A.C. Assessment and statistics of Brazilian hydroelectric power plants: Dam areas versus installed and firm power. Renew. Sustain. Energy Rev. 2008, 12, 1843-1863. [CrossRef]

4. Ledec, G.; Quintero, J.D. Good Dams and Bad Dams: Environmental Criteria for Site Selection of Hydroelectric Projects; Latin America and Caribbean Region Sustainable Development Working Paper Series, No. 16; World Bank Group: Washington, DC, USA, 2003; Volume 16, p. 21.

5. Sousa Júnior, W.C.; Reid, J. Uncertainties in Amazon hydropower development: Risk scenarios and environmental issues around the Belo Monte dam. Water Altern. 2010, 3, 249-268.

6. Locher, H. Environmental issues and management for hydropower peaking operations. Small Hydro Power News 2005, 22, 15-19.

7. Akpinar, A.; Kömürcü, M.H.; Kankal, M. Development of hydropower energy in Turkey: The case of oruh river basin. Renew. Sustain. Energy Rev. 2011, 15, 1201-1209. [CrossRef]

8. Wei, S.; Zhang, L. Vibration analysis of hydropower house based on fluid-structure coupling numerical method. Water Sci. Eng. 2010, 3, 75-84. [CrossRef]

9. Al-Juboori, A.M.; Guven, A. Hydropower plant site assessment by integrated hydrological modeling, gene expression programming and visual basic programming. Water Resour. Manag. 2016, 30, 2517-2530. [CrossRef]

10. Heckelsmueller, G.P. Application of variable speed operation on Francis turbines. Ing. Investig. 2015, 35, 12-16. [CrossRef]

11. Palla, A.; Gnecco, I.; La Barbera, P.; Ivaldi, M.; Caviglia, D. An integrated GIS approach to assess the mini hydropower potential. Water Resour. Manag. 2016, 30, 2979-2996. [CrossRef]

12. Gui, M.-W.; Chiu, H.-T. Seismic response of Renyitan earth-fill dam. J. Geoengin. 2009, 4, 41-50.

13. Anup, K.C.; Thapa, B.; Lee, Y.H. Transient numerical analysis of rotor-stator interaction in a Francis turbine. Renew. Energy 2014, 65, 227-235. [CrossRef]

14. Bahrami, S.; Tribes, C.; Devals, C.; Vu, T.C.; Guibault, F. Multi-fidelity shape optimization of hydraulic turbine runner blades using a multi-objective mesh adaptive direct search algorithm. Appl. Math. Model. 2016, 40, 1650-1668. [CrossRef] 
15. Bouaanani, N.; Paultre, P.; Proulx, J. A closed-form formulation for earthquake-induced hydrodynamic pressure on gravity dams. J. Sound Vib. 2003, 261, 573-582. [CrossRef]

16. Qian, Z.; Yang, J.; Huai, W. Numerical simulation and analysis of pressure pulsation in Francis hydraulic turbine with air admission. J. Hydrodyn. Ser. B 2007, 19, 467-472. [CrossRef]

17. Zhang, R.; Mao, F.; Wu, J.Z.; Chen, S.Y.; Wu, Y.L.; Liu, S.H. Characteristics and control of the draft-tube flow in part-load Francis turbine. J. Fluids Eng. 2009, 131, 21101. [CrossRef]

18. Pennacchi, P.; Borghesani, P.; Chatterton, S. A cyclostationary multi-domain analysis of fluid instability in Kaplan turbines. Mech. Syst. Signal Process. 2015, 60, 375-390. [CrossRef]

19. Zhang, H.; Zhang, L. Numerical simulation of cavitating turbulent flow in a high head Francis turbine at part load operation with OpenFOAM. Procedia Eng. 2012, 31, 156-165. [CrossRef]

20. Kim, J.; Yoon, J.C.; Kang, B.-S. Finite element analysis and modeling of structure with bolted joints. Appl. Math. Model. 2007, 31, 895-911. [CrossRef]

21. Yang, Y.; Chen, J.; Xiao, M. Analysis of seismic damage of underground powerhouse structure of hydropower plants based on dynamic contact force method. Shock Vib. 2014, 2014, 859648. [CrossRef]

22. Dai, F.; Li, B.; Xu, N.; Zhu, Y.; Xiao, P. Stability evaluation on surrounding rocks of underground powerhouse based on microseismic monitoring. Shock Vib. 2015, 2015, 937181. [CrossRef]

23. Fenves, G.; Chopra, A.K. Simplified earthquake analysis of concrete gravity dams: Separate hydrodynamic and foundation interaction effects. J. Eng. Mech. 1985, 111, 715-735. [CrossRef]

24. Watanabe, H.; Kikuchi, K.; Cao, Z. Vibration modes of a rockfill dam based on the observations of microtremors and an earthquake. Thammasat Int. J. Sci. Technol. 1996, 1, $22-37$.

25. Lotfi, V. Seismic analysis of concrete gravity dams by decoupled modal approach in time domain. Electron. J. Struct. Eng. 2003, 3, 102-116.

26. Jafari, M.K.; Davoodi, M. Dynamic characteristics evaluation of Masjed-soleiman embankment dam using forced vibration test. In Proceedings of the 13th World Conference on Earthquake Engineering, Vancouver, BC, Canada, 1-6 August 2004.

27. Mircevska, V.J.; Bickovski, V.; Garevski, M. A 3D nonlinear dynamic analysis of a rock-fill dam based on IZIIS software. Acta Geotech. Slov. 2007, 4, 16-32.

28. Lipej, A.; Jošt, D.; Meznar, P.; Djelic, V. Numerical prediction of pressure pulsation amplitude for different operating regimes of Francis turbine draft tubes. Int. J. Fluid Mach. Syst. 2009, 2, 375-382. [CrossRef]

29. Jošt, D.; Lipej, A. Numerical prediction of non-cavitating and cavitating vortex rope in a francis turbine draft tube. Stroj. Vestn. J. Mech. Eng. 2011, 57, 445-456. [CrossRef]

30. Dakoulas, P. Longitudinal vibrations of tall concrete faced rockfill dams in narrow canyons. Soil Dyn. Earthq. Eng. 2012, 41, 44-58. [CrossRef]

31. Adamo, N.; Al-Ansari, N. Mosul dam full story: Safety evaluations of mosul dam. J. Earth Sci. Geotech. Eng. 2016, 6, 185-212.

32. Sissakian, V.K.; Adamo, N.; Al-ansari, N. A comparative study of mosul and haditha dams, Iraq: Geological conditions. Earth Sci. Geotech. Eng. 2018, 9040, 35-52.

33. Liu, S.; Li, S.; Wu, Y. Pressure fluctuation prediction of a model Kaplan turbine by unsteady turbulent flow simulation. J. Fluids Eng. 2009, 131, 101102. [CrossRef]

34. Vilanova, M.R.N.; Balestieri, J.A.P. Modeling of hydraulic and energy efficiency indicators for water supply systems. Renew. Sustain. Energy Rev. 2015, 48, 540-557. [CrossRef]

35. Samora, I.; Hasmatuchi, V.; Münch-Alligné, C.; Franca, M.J.; Schleiss, A.J.; Ramos, H.M. Experimental characterization of a five blade tubular propeller turbine for pipe inline installation. Renew. Energy 2016, 95, 356-366. [CrossRef]

36. Temiz, A. Decision Making on Turbine Types and Capacities for Run-of-River Hydroelectric Power Plants a Case Study on Eglence-1 Hepp. Master's Thesis, İzmir Institute of Technology, İzmir, Turkey, 2013.

37. Feintuch, P. The international electrotechnical vocabulary of the international electrotechnical commission. Meta 1989, 34, 539-541. [CrossRef]

38. Becker, D. Harmonizing the International Electrotechnical Commission Common Information Model (Cim) and 61850; Technical Report; Electric Power Research Institute (EPRI): Palo Alto, CA, USA, 2010. 
39. Muis, A.; Sutikno, P.; Soewono, A.; Hartono, F. Design optimization of axial hydraulic turbine for very low head application. Energy Procedia 2015, 68, 263-273. [CrossRef]

40. Slootweg, J.G.; de Haan, S.W.H.; Polinder, H.; Kling, W.L. General model for representing variable speed wind turbines in power system dynamics simulations. IEEE Trans. Power Syst. 2003, 18, 144-151. [CrossRef]

(C) 2018 by the authors. Licensee MDPI, Basel, Switzerland. This article is an open access article distributed under the terms and conditions of the Creative Commons Attribution (CC BY) license (http://creativecommons.org/licenses/by/4.0/). 